\title{
Croatia's Knowledge Production on Kosovo around 1989
}

Janković, Branimir

Source / Izvornik: Comparative Southeast European Studies, 2021, 69, 267 - 287

Journal article, Published version

Rad u časopisu, Objavljena verzija rada (izdavačev PDF)

https://doi.org/10.1515/soeu-2021-0041

Permanent link / Trajna poveznica: https://urn.nsk.hr/urn:nbn:hr:131:553303

Rights / Prava: Attribution-NonCommercial-NoDerivatives 4.0 International/ImenovanjeNekomercijalno-Bez prerada 4.0 međunarodna

Download date / Datum preuzimanja: 2023-04-26

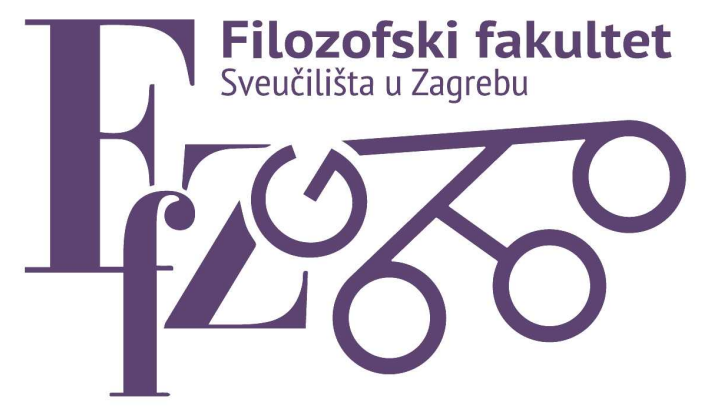

Repository / Repozitorij:

ODRAZ - open repository of the University of Zagreb

Faculty of Humanities and Social Sciences
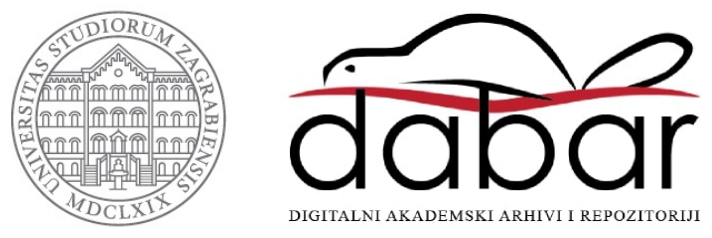


\title{
Kosovo in the Yugoslav 1980s
}

\author{
Branimir Janković*
}

\section{Croatia's Knowledge Production on Kosovo around 1989}

https://doi.org/10.1515/soeu-2021-0041

\begin{abstract}
In socialist Yugoslavia in 1989 the extremely sensitive matter of Kosovo had an ambiguous effect on the League of Communists of Croatia, which was then still caught in the so-called "Croatian silence". It did however provoke much turbulence in the Croatian media, which made pointed comments on the larger Yugoslav crisis, on the situation in Kosovo, and on the politics of Serbian president Slobodan Milošević. An intense dynamic could be also found in the field of knowledge production which encompassed scholars, historians, and intellectuals. Who produced knowledge about Kosovo? What were their political and intellectual agendas? How did they intervene in the dominant discourses and media coverage, what debates and reactions did they spark? Within the frames of the history of knowledge, the history of books and intellectual history, the author here assesses the works on Kosovo of a number of Croatian and Yugoslav intellectuals, chiefly Darko Hudelist and Branko Horvat.
\end{abstract}

Keywords: Yugoslavia, Kosovo, Croatia, knowledge production, intellectual history

\section{Introduction}

In 1988 the prominent Yugoslav economist Branko Horvat wrote in the first edition of his book "The Kosovo question" that a great deal more had been published about Kosovo in the past few years than at any other time in the entire existence of Yugoslavia. He believed that as a result Yugoslavs now knew more about each other, which would have an integrating effect. According to Horvat, Kosovo was only then being truly integrated into Yugoslavia, regardless of the political conflicts over the province at the time $(1988,117)$. However, contrarily to

\footnotetext{
*Corresponding author: Branimir Janković, Department of History, Faculty of Humanities and Social Sciences, University of Zagreb, Zagreb, Croatia. E-mail: bjankovi@ffzg.hr

๖ Open Access. ๑ 2021 Branimir Janković, published by De Gruyter. (๔) Br-Nc-ND This work is licensed under the Creative Commons Attribution-NonCommercial-NoDerivatives 4.0 International License.
} 
his hopes, not only was the Kosovo matter not resolved, but Yugoslavia itself disintegrated. It turned out that books about Kosovo published in the 1980s had been written not only with the aim of acquainting the public with the history of and conditions in modern Kosovo, but also as a means of addressing the political struggle directly.

Kosovo has generated not only extremely conflicting interpretations in Serbian, Albanian, Yugoslav and international historiography, but has stimulated the production of rich knowledge also. The recent rise of interest in the history of knowledge has provided new perspectives and concepts that can be applied to the whole field of study of Kosovo. The conflicts in Kosovo in 1989 as well as those in 1981 and 1998-1999 concerned not only political questions but knowledge too, and were carried out through the production of knowledge. What was the truth about Kosovo, and what was happening there in general? Is what was presented as objective knowledge about Kosovo actually rather a subjective view? Obviously, in the case of Kosovo these are "knowledges in the plural" which we can talk about as conflicted and positioned, or "situated knowledges" (Burke 2015, 7-14, 33-4) depending on whether they came from Kosovo, Serbia, one of the other Yugoslav republics (Slovenia, Croatia, Bosnia and Herzegovina, Montenegro and Macedonia), or abroad. As a rule all such knowledge is marked by the specific political situation in the country from which it originated.

In the example of Kosovo we can talk about a certain "geopolitics of knowledge", which includes the question of "the relationship between intellectual centers and their peripheries" (Burke 2015, 33). This refers on the one hand to Kosovo, which the actors at the time perceived as the Yugoslav periphery, and on the other hand to the attitude of Belgrade, as the republican and federal centre, to Pristina as the provincial centre; but also the attitudes of the republican centres of Zagreb and Ljubljana to both Belgrade and Pristina. In the case of Kosovo there was a certain "hierarchy of knowledge", with Yugoslav and the Serbian knowledge as "dominant knowledges" and Albanian knowledge for example as one of the "subjugated knowledges", as well as knowledge such as the Slovenian and Croatian ones that were somewhere in between. All of that tends to confirm Burke's observation that "different kinds of knowledge had different centers at different times” (Burke 2015, 34).

In the multinational Yugoslav federation, where different interests clashed, there was on the one hand a lack of knowledge about Kosovo and the ignoring and even active suppression of certain knowledge, but on the other hand the "dominant knowledges" were questioned and the official knowledge was rejected-the knowledge of the communist authorities as represented by party resolutions, the press and the sharp polemics of the parties to the conflict. Here too the case of Kosovo fits very well into the approaches of the knowledge studies 
field: "Just as studies of memory have expanded to include the complementary opposite topic of forgetting, knowledge studies are coming to include studies of ignorance, including knowledge that has been lost or consciously rejected" (Burke 2015, 14).

In this article I shall discuss the production of knowledge about Kosovo in Croatia around 1989 and the intellectuals who were engaged with the Kosovo question. The case of Kosovo in Yugoslavia is particularly interesting from the perspective of knowledge production. It has not been researched in this manner in the extensive literature, neither in that about Kosovo in general nor in that about the "nationalist mobilization" of intellectuals and mass movements around Kosovo (Bieber 2002). Therefore I shall first offer a few general remarks about Croatia's attitude to Kosovo in the 1980s, and then discuss intellectuals and especially books about Kosovo that were published in the Socialist Republic of Croatia (henceforth SR Croatia) in the late 1980s and, after the break-up of Yugoslavia, in the Republic of Croatia. My special focus is on books because they are an important means of knowledge production and tend to trigger heated public debate. While my focus is on Croatia I shall address too the broader question of the role of intellectuals in the break-up of Yugoslavia.

\section{The Kosovo Question from a Croatian Perspective}

Kosovo is no longer an important topic in today's Croatian politics, media nor historiography. Nor is Yugoslavia a popular topic any longer; indeed mention of it causes controversy in mainstream politics, media and historiography because of the assumption that the Republic of Croatia was created in opposition to Yugoslavia (Grandits, Ivanović, and Janković 2019). Therefore, the shared past of Croatia and Kosovo in Yugoslavia is completely out of the picture, with interest reduced to the current conflict and political negotiations between Kosovo and Serbia. Croatia views Kosovo from the perspective of its own Croat-Serb conflict and war, although there is no specific interest in Kosovo as such. Confirmation of the lack of interest in Kosovo may be seen from contemporary Croatian historiography, which has provided almost no works on Kosovo since Yugoslavia's disintegration.

Kosovo is rarely mentioned in books on the history of Yugoslavia. For Croatian historians, writing the history of Yugoslavia means focusing mainly on Croatian history or conflict between Croats and Serbs. From that point of view, Slovenia, Bosnia and Herzegovina, Montenegro, Macedonia and Kosovo serve only as the context for Croatian-Serbian history. Indeed, only Macedonia occupies a more difficult position than Kosovo in Croatian historiography, the implicit assumption 
being that nothing important to Croatian history, Croatian-Serbian relations in Yugoslavia, nor the break-up of Yugoslavia occurred in Macedonia. However, that is a problem not only of Croatian historiography but of all post-Yugoslav historiographies that predominantly deal with their own national history. Therefore, in Croatian historiography Kosovo in 1989 features only as part of the anti-bureaucratic revolution of 1988-9 led by Slobodan Milošević, which continued with the Serb uprising in Croatia in 1990. Although in Croatia there is no specific or continuing interest in Kosovo, there was certainly a peak of interest in 1989 during the culmination of the Kosovo crisis and the onset of the general Yugoslav crisis.

In those years Croatian politics were still determined by the so-called "Croatian silence", which lasted from the fall of the Croatian Spring-or the mass movement (maspok) of the early 1970s-until deep into the 1980s, at the end of which decade Croatia's communist leaders even avoided explicit public condemnation of Miloševićs anti-bureaucratic revolution. That was because of the legacy not only of World War II-era Croatian nationalism but that of the Croatian Spring too which, unlike Serbian nationalism, was considered separatist. The same approach was reflected in the attitude to Kosovo shown by the League of Communists of Croatia. Despite in 1989 not supporting the Socialist Republic of Serbia's (SR Serbia) calls for the abolition of the Socialist Autonomous Province of Kosovo (SAP Kosovo), Croatian communist leaders nevertheless remained silent on the subject. Ironically because of that attitude, both the SR Croatia and the SR Slovenia found themselves attacked in the Serbian media for withholding direct support for Serbia's policy on Kosovo (Marijan 2017, 1302; Pauković 2018, 50-1).

However, apart from the sensitive nature of the 1989 Kosovo crisis for the whole of Yugoslavia, one particular event in the SR Croatia was to become extremely challenging for the League of Communists of Croatia. In the summer of 1989, at the very moment the famous gathering on 28 June 1989 was taking place at Kosovo Polje near Pristina on the occasion of the 600th anniversary of the Battle of Kosovo (1389-1989), a meeting was being held in Croatia. Not only that, but several thousand supporters of the Serbian policy on Kosovo gathered on 9 July at a rally at the village of Kosovo Polje near Knin, which later became a centre of the Serb uprising in Croatia in 1990. That gathering was part of a broader attempt by Milošević to export such rallies to the other republics-beginning with Kosovo-with the aim of subjecting the authorities there to the interests of the SR Serbia. Milošević sought to introduce the same sort of rallies to Vojvodina and Montenegro, and ultimately to Croatia and even Slovenia, in 1989 (Hudelist 1989, 9, 228, 322-3, 336; Bilandžić 2006, 339; Marijan 2016, 439-66).

The gathering in the SR Croatia at Kosovo Polje attracted Serbs both from Croatia and other areas-Kosovo, Vojvodina, Montenegro and Serbia. They 
displayed iconic images and shouted slogans opposing the policy of the Yugoslav party and the Croatian communist authorities. Completely in line with the socalled anti-bureaucratic revolution then underway, they raised questions about the status of Serbs in Croatia. Forced to react, the Croatian communist leaders publicly condemned nationalist and antisocialist incidents and provocations. However, their condemnation was not harsh and lower-ranking communist politicians were able to apply pressure from below to ask the Croatian communist authorities to stop the general condemnation and instead question the responsibility of Slobodan Milošević (Marijan 2016).

So it was that not even the extremely sensitive Kosovo question in 1989 and the attempts to cause it to spill over into the SR Croatia-with the common theme being the position of Croatian Serbs-managed completely to break the so-called "Croatian silence" in the politics of the League of Communists of Croatia. That is why the SR Croatia did not engage in the Kosovo question in 1989, while the SR Slovenia supported the Kosovo Albanians, for example at the rally at Cankarjev dom in Ljubljana (Ramšak 2021, in this issue). Still, the Kosovo question did indeed turn out to represent the beginning both of the gradual breaking of that "Croatian silence" and of opposition to Milošević's policies, although the emphasis remained on Croat-Serb relations and the SR Croatia's position vis à vis the SR Serbia. In the SR Croatia the effort at "breaking the silence" was spearheaded by the media, which asserted itself more and more in the late 1980s, with newspapers such as Vjesnik and especially Danas sharply criticizing the anti-bureaucratic revolution led by Slobodan Milošević. The papers were joined by magazines like Start, as well as student newspapers which often overstepped the mark by addressing taboo topics, as I recall well, so that a number of articles on Kosovo were withdrawn or sanctioned. It proved difficult to gain access to audiovisual archives so the investigation of television and radio coverage in Croatia around 1989 has had to remain beyond the possibilities of this research. However, my assumption is that for the most part television and radio followed the newspapers' line.

It should be borne in mind that the atmosphere among the Yugoslav publics in the late 1980s was extremely tense. Journalists and intellectuals warned that the continuing conflicts were leading to the disintegration of the Yugoslav state and civil war; or that a civil war was already going on and that there was no longer any possibility of any sort of dialogue, even among the well-informed. Everything in Yugoslavia in the late 1980s took place in an atmosphere of general crisiseconomic, political, ideological and social-and was played out against a backdrop of collapsing communist regimes in Eastern Europe. All of this was reflected not only in the attitude of Croatian politics and the media to the Kosovo and Yugoslav crises, but also in Croatian knowledge production about Kosovo. While it is undoubtedly true that the SR Croatia was not a neutral observer of the Kosovo 
issue and the Serb-Albanian confrontation, it might all the same have been able to offer a third-party perspective.

\section{Croatia's Knowledge Production on Kosovo around 1989}

To speak about the Kosovo question from the perspective of the history of knowledge means to ask the following questions: Who produced knowledge about Kosovo in Yugoslavia and abroad; and what kind of knowledge about Kosovo was circulating? Who in the SR Croatia, or in the rest of Yugoslavia, published books during the 1980s about Kosovo, and since? From what position and for what purposes were those books published? Which books made enough of an impression to spark heated discussions and to be used in various milieus? Questions about books and intellectuals must be linked to political history and the major sociopolitical disputes of the time.

One book in which these questions can be analysed is Kosovo: A Short History by the historian Noel Malcolm (1998). Because of the war in Kosovo in 1998-9 the book had a wide reception both internationally and in southeastern Europe. There were both Albanian and Bosnian editions of the book which came to the attention of Croatians too and generated sharp reactions from Serbians (cf. Stefanov 2010). In addition to books such as Malcolm's that garnered international and regional attention, other books were important within specific local contexts. The importance of books consists not only in their own political, social, and intellectual history, but in that they can address questions and events in different ways; indeed in certain circumstances they are the only way it becomes possible to express what cannot be stated openly by politicians or the media (Janković 2019).

In the following I shall focus on books about Kosovo published in the SR Croatia during the turbulent events in Kosovo from 1981-9 looking especially closely at the height of the crisis in 1989, but not forgetting the years that followed. The point is not simply to identify authors who engaged with Kosovo and their books, but rather to consider their political implications contemporaneously in the midst of the Yugoslav crisis. A large number of politicized books confirm the huge importance of the Kosovo question in Yugoslavia, as well as the role of intellectuals. I wish in fact to illustrate the increasing politicization of knowledge production about Kosovo both while Yugoslavia still existed and after its dissolution, and to highlight how extensive and deep that process gradually became and how it still persists. 
For a long time, books about Kosovo were not published in the SR Croatia, largely because there was no interest in the subject until the mass protests by Kosovo Albanians in 1981 (Limani Myrtaj 2021, in this issue). Shortly thereafter Žarko Panjković published Kosovo i albanska iredenta (Kosovo and the Albanian irredenta) in Rijeka (1981). In it he expressed the official view of the Yugoslav communist authorities and condemned the "counter-revolution", Albanian nationalism, and irredentism. From the mid-1980s-and especially in 1989books were published that would present more heterogeneous views. Then, in 1986 a book was published in Zagreb that to an extent presented an Albanian view of the history and modernity of Kosovo. The author of Kosovo: istine $i$ zablude (Kosovo: truths and misconceptions) was Sinan Hasani, an Albanian writer, Yugoslav politician, one of the leaders of the League of Communists of Kosovo and president of the Socialist Federal Republic of Yugoslavia (SFRY) between 1986 and 1987 (1986a). In the same year Hasani published Kosovska uzrastanja i posrtanja (Kosovo's growth and stumbling) in Belgrade, which provoked sharp reactions from Serbian intellectuals (1986b). Hasani's position was characteristic of Albanian communist politicians, who from the standpoint of the League of Communists of Yugoslavia tended to criticize the 1981 "counterrevolution", but also presented the history of the Albanian people in a way that was more complex than the Serbian and Yugoslav public realized.

Certainly, those published works were part of a broader knowledge production about Kosovo that grew all over Yugoslavia at the time. In Belgrade and Pristina especially, many political scientists, sociologists, historians, and literary scholars published books on both historical and contemporary topics and by the end of the 1980s Croatian and Slovenian authors had gradually joined the field. Albanian and Serbian émigré authors too were involved, and various publications were translated into foreign languages. In what could be called a veritable "war of books", going on alongside the wars in politics and the media, many books attempted to intervene directly in the public controversy, or had political goals, or were even intended to be used as weapons in the political struggle.

For example, in the SR Serbia the publisher Politika commissioned special editions of publications dealing with Kosovo, and many local actors both in Kosovo and the rest of Yugoslavia read not only the antagonistic press but also other newly-published works on the Battle of Kosovo of 1389, particularly apposite in the light of its 600th anniversary (Hudelist 1989, 291-306). All such activity was the culmination of a breakthrough in popular history in the 1980s not only on the matter of Kosovo but also on World War II and other Yugoslav historical controversies. It was followed in Croatia by highly politicized articles published in the Croatian and broader Yugoslav press, and in 1989 by polemics in the Croatian and Serbian press, one of the main triggers of which was the books and intellectual 
interventions on Kosovo. All drew severe reactions throughout Yugoslavia but most pointedly in the SR Serbia, the SAP Kosovo, the SR Croatia, and the SR Slovenia.

In the SR Croatia, as in the rest of Yugoslavia, politicians and journalists were first engaged in public discussions on the Kosovo question in political forums and the media. Some of them even published books on the topic, which represented not only a means of knowledge production but also an opportunity for deeper intervention in the political struggles over how to interpret Kosovo. Gradually, as the crisis intensified, public intellectuals whose primary expertise was not Kosovo became involved in the controversy. Finally, in 1989 at the height of the Kosovo and Yugoslav crisis, polemical books about Kosovo were published in the SR Croatia too by public intellectuals, social scientists and journalists.

Croatian historians meanwhile, unlike the journalists and intellectuals, did not address Kosovo. Instead they spent the 1980s primarily arguing with Serbian historians over topics related to Croatian-Serbian relations, most prominently World War II and the Ustasha death camp at Jasenovac. Even at the height of the 1989 crisis Croatian historians did not believe that Kosovo was significant to Croatian history. In any case, preferring historical “distance”, most historians in the SR Croatia refrained from dealing with recent history and few of them acted as public intellectuals. In fact, the only ones who did perceive that Kosovo was a key subject for Yugoslavia in the late 1980s and joined the discussion about it were a small number of Croatian historians-like Dušan Bilandžić-who were members of the League of Communists. However, even Bilandžić's emphasis was primarily on the policy of the SR Serbia and on how the SR Croatia should approach it as part of the broader Croatian-Serbian relationship, the Yugoslav crisis, the collapse of communism, and the survival of Yugoslavia. Indeed, Bilandžić had no particular interest in Kosovo itself (Bilandžić 2006, 311-41). Between them-although with the exception of the journalist Darko Hudelist and the above-mentioned social scientist and public intellectual Branko Horvatneither the historians in Croatia nor any other scholars specialising in the history and culture of Albania and Kosovo managed to publish a single book on Kosovo in or near 1989.

All of this confirms that many intellectuals in Croatia remained excluded from the controversy over Kosovo. In fact they were caught up in the "Croatian silence" and avoided sharp public debates. But that only makes the few journalists and public intellectuals who did involve themselves even more interesting. Darko Hudelist's and Branko Horvat's books provoked numerous reactions in the Yugoslav media and among intellectuals and their cases clearly mirror not only the 
growing politicization in Yugoslavia of the Kosovo question but also the large sociopolitical divisions it was causing.

\section{Darko Hudelist: Who Was Behind the Rallies in Kosovo?}

Today, Darko Hudelist is a prominent journalist and publicist in Croatia, but 30 or so years ago as a young professional he dedicated his first book to Kosovo, Kosovo: Bitka bez iluzija (Kosovo: A battle without illusions) (1989). Since the newspapers reported very differently on Kosovo depending on whether they were published in Serbia, Slovenia or Croatia, Hudelist in 1987 and 1988 travelled to Kosovo and spoke to participants in the events of that time. In the resulting book he ventured into a type of journalism that was new to Yugoslavia: evaluative journalism, an approach that would become characteristic of many of his books. In the 2000s, Hudelist published another book, this time drawing on conversations he had had over the years with Dobrica Ćosić, the Serbian political and intellectual leader (Hudelist 2012). In 2004 Hudelist wrote a critical biography of the first president of independent Croatia, Franjo Tuđman (Hudelist 2004).

Also in his first book, under discussion here, Hudelist took an individual interest in key figures in politics, focusing on the controversial Serbian political leader in Kosovo, Miroslav Šolević, with whom he spoke at length (Hudelist 1989). The book's career began tumultuously with a banned article about Šolević in the magazine Start (18 March 1989), in the feuilleton section, of which Hudelist's book was to feature. The book was based on his previously published reports in the magazine. Start was not the only Croatian youth outlet that was to experience bans on articles about Kosovo in 1989, but the ban on the report of this particular conversation with Šolević aroused numerous reactions throughout Yugoslavia. Šolević had announced plans for rallies intended to overthrow the communist leadership of Croatia and Slovenia, actions intended as a continuation of the "anti-bureaucratic revolution" that had begun in Kosovo and was continuing in Vojvodina and Montenegro. Much of the Croatian public criticized the ban, saying that everyone should see what was behind the allegedly spontaneous rallies of Serbs and Montenegrins. The Serbian press attacked the Slovenian and Croatian press for using Šolević to attack the Serbian communist leaders. Hudelist's observation was thus confirmed, that the newspapers reacted promptly to events while politicians were slow to respond. The discursive war between newspapers was at work; they had turned into means of political struggle and nationalism had taken over. Hudelist referred in his book to the words of commentators who were 
warning that things had gone beyond discussion, dialogue and academic debate, but at the same time he himself added to the controversy by criticizing what some intellectuals were saying (Hudelist 1989, 345, 363, 367, 381).

Similarly to other books on Kosovo in those years, 10,000 copies of Hudelist's book were issued, which confirms the great public interest in the topic. The publisher's preface $(1989,5)$ pointed out that the book offered a fresh look at the "Rashomon effect" left by the Kosovo tragedy, a reference to the well-known treatise on the subjectivity of truth and knowledge by the filmmaker Akira Kurosawa, in which three different characters give three differing views-all ostensibly true-of the same event in which all were involved. The coining thus acknowledges the enormous significance of the question of what is true and who is right, obviously of special importance to knowledge production about Kosovo. Hudelist sought the answer to that question by talking to people his fellow Croatian journalists avoided because they did not agree with them-the participants in the events. Hudelist particularly sought out those from the Serbian national movement in Kosovo $(1989,12)$, which was precisely why Hudelist deemed it necessary to go to Kosovo, so that he could meet the actors themselves, to hear their story. He knew they had good reason to trust neither politicians nor the media, but because of his own focus on the Serbian national movement and its leaders, Hudelist preferred Serbian actors over Albanian ones. Only when researching his book did Hudelist realize that these were not the ephemeral events they were generally considered to be. Until then Hudelist too had followed events in Kosovo throughout the 1980s from a distance, little interested in what was happening in a province about which he knew almost nothing and which seemed both backward and geographically and culturally distant (1989, 17). Hudelist's lack of both knowledge and interest was characteristic of Croatian knowledge production about Kosovo and affirms Burke's observation that knowledge is "situated" (Burke 2015, 9-14, 33-4).

However, as the broader Yugoslav public increasingly began to pay attention to Kosovo and as the international public began to be aware of the "anti-bureaucratic revolution" and the state crisis in Yugoslavia, certain Croatian intellectuals too began gradually to become involved. However, when Hudelist invited them to discuss his book and media publications, only the economist Branko Horvat and the historian Dušan Bilandžić responded. Those who refused to participate said they were insufficiently informed; that Kosovo was a sensitive subject. Furthermore, by saying that it was an internal matter for Serbia in which Croatia should not interfere, they betrayed their concern about Belgrade's reaction. Some claimed that it was already too late to discuss the subject (Hudelist 1989, 83). Although by exposing Šolević's views Hudelist had revealed the fake spontaneity of the "anti-bureaucratic revolution" rally, he had no wish to act as arbiter between 
Kosovar Serbs and Albanians. In the preface, the publisher adhered to the policy that was typical of the Yugoslav communist authorities and condemned Serbian and Albanian nationalism alike. In accordance with the official party position Hudelist called the demonstrations in Kosovo of 1981 a counter-revolution. Among other reasons that was why his book won the Award of the Seven Secretaries of the League of Young Communists of Yugoslavia (Savez komunističke omladine Jugoslavije, SKOJ) in 1989.

Darko Hudelist played an important role in reporting and explaining the Yugoslav crisis, but also in fuelling it. As a journalist focusing on the leaders of the Serb national movement in Kosovo he provided challenging reports from Kosovo, presenting what had been taboo in the media and therefore in politics too. However, he never questioned the regime's official assessment of the demonstrations of 1981. Neither did he go into detail about the demands to make Kosovo into Yugoslavia's seventh republic, nor did he engage with potential solutions to the ongoing crises. Economist and public intellectual Branko Horvat went a step further, attempting to soothe the discourses about Kosovo. Horvat truly believed not only that something needed to be done but that something actually could be done to overcome the crisis.

\section{Branko Horvat: The Range and Limits of Intellectual Activity}

As the only scholar from the SR Croatia to write a book about Kosovo at the height of the crisis there, Branko Horvat delved into the core of political qualifications and dominant narratives about the Serb-Albanian conflict and the Kosovo question. At the time, with an international reputation, he was one of Yugoslavia's most prominent scholars and had authored books on the political economy of socialism, among other topics (Franičević and Uvalić 2000). Critical of the regime, Horvat was an advocate of both socialism and Yugoslavia, which was the position from which he published Kosovsko pitanje (The Kosovo question) in 1988, which saw a second, supplemented edition in 1989. Similarly to Hudelist, Horvat had begun publishing articles about Kosovo in 1987, from which his 1989 book later emerged (Horvat 1988, 5, 151, 159, 171, 177).

While Hudelist provoked public controversy by exposing the deception undertaken by the Serb leaders of the allegedly spontaneous gatherings in Kosovo, Horvat achieved the same end by refusing to use the widely accepted term "counter-revolution" for the 1981 demonstrations and by showing understanding for Albanian demands that Kosovo become a republic within Yugoslavia. Horvat 
also opposed the use of the term "genocide" against Kosovar Serbs and Montenegrins, which was used by much of the Serbian public (Horvat 1988, 11-2, 10918, 159-64). He believed that 1981 was not a counter-revolution but a national uprising and that demands for a Republic of Kosovo within Yugoslavia-which was punished by the authorities-was not counter-revolutionism but rather a legitimate political demand. Horvat saw the SAP Kosovo as a de facto republic, which precisely allowed for the possibility, when the proper conditions were created, for Kosovo to become an official republic (Horvat 1988, 11-2, 103-8). Politics had simply gone the opposite way, with the SR Serbia under Slobodan Milošević revoking Kosovo's autonomy.

Horvat was equally willing to consider the question of unifying Albanians from Kosovo with Albania proper, acknowledging that in principle they had the right to do so. However, he maintained that it should happen only within some future Balkan federation, for example between Yugoslavia and Albania. The idea of a Balkan federation had been advocated both by the Yugoslav social democrats in the early 20th century and the Yugoslav communists in the mid-20th century (Horvat 1988, 137-8, 141-7). Horvat opposed the secession of Kosovo, advocating instead the integrity of the Yugoslav federation and within it the better integration of Kosovo and its Albanian population. He asked whether Yugoslavia was a state of only South Slavs or whether there was room in it for Albanians too, whether in fact Albanians were “ours" or "foreign" (Horvat 1988, 145-6). Horvat placed Kosovo in the context of the wider Yugoslav crisis about which he had written Jugoslavensko društvo u krizi (The Yugoslav society in crisis) (1985).

Horvat never thought the problem of Kosovo was insoluble, instead continuing to believe that a rational solution was possible. His fellow intellectuals, however, warned him that things had gone beyond reasoning and that he would be severely attacked. Nevertheless, Horvat remained convinced that intellectuals had a responsibility to engage in a general, Yugoslav, discussion for the future of the country, and that Albanian intellectuals were not being listened to, while other Yugoslav intellectuals had kept silent. Like Hudelist, Horvat too pointed out that before this crisis he, just like the average Yugoslav, had known almost nothing about Kosovo or the history of the Albanians. The great shortcoming of his own book on the Kosovo question, he maintained, was that he did not know Albanian. Just as Yugoslavia had seen the first serious books about Kosovo appear only a year or two earlier, this was another example of the Yugoslav peoples' more generally knowing very little about each other. Horvat pointed to the existing barriers to meaningful communication $(1988,6,119)$ confirming how he saw Kosovo and the Yugoslav crisis more generally as a problem of knowledge-that is of knowledge production.

As an avowedly Yugoslav intellectual, Horvat was critical of Croatian, Serbian and Albanian nationalism because he saw each of them as a danger to 
multinational Yugoslavia, which could lead not only to disintegration but even to war. Many of his views were unusual to the public of that time and aroused great interest, however much of the controversial reaction focused on Horvat's understanding of the "appeal for a Republic of Kosovo" which was perceived as extremely incendiary-in fact a veritable political bombshell (Hudelist 1989, 90-1). Horvat documented the criticism and attacks by politicians, journalists and intellectuals in the Serbian press in the second edition of "The Kosovo question" in 1989 (Horvat 1989, 205-308). He noted too that 11 Albanians had been jailed for membership of a Marxist-Leninist group and that one of their crimes had been the possession of his book (Horvat 1989, 14). Journalists who interviewed him were sanctioned, among them Aleksandar Tijanić in Start and Veton Surroi in the Kosovo newspaper Rilindja. Surroi's interview with Horvat published in Rilindja in particular provoked numerous attacks both in the Serbian press and from politicians who claimed that Horvat supported the Albanian separatists (Horvat 1989, 285-6).

Horvat responded by engaging in further debate-after all, "The Kosovo question" had originated in controversies over historical debates he had himself had in magazines and newspapers, for example with the Serbian historian Branko Petranović. Horvat had complained about the frequent failure of the Serbian press to publish his responses (Horvat 1988, 171). On the other hand, the Croatian and Slovenian press had begun to show great interest in publishing Horvat's writings, and Horvat now believed that newspapers were writing more freely, in fact that a free Yugoslav public opinion was finally emerging. Still, as he pointed out now citing his case, the public were increasingly antagonistic, and national homogenizations and propaganda in the media were being thus exposed. Other commentators noticed the same thing and expressed their doubts that intellectuals would have any impact that might lead towards change. However, Horvat continued to point to what he believed to be the obligation of intellectuals more generally. While in Slovenia there was debate on Kosovo among intellectuals, the same was impossible in Kosovo itself. In Horvat's opinion, intellectuals in Yugoslavia had not lived up to their obligations, as demonstrated by the failure of dialogue between Serbian and Albanian writers in Belgrade in 1988. Horvat especially condemned the words addressed by Serbian writer Milan Komnenić to his Albanian colleagues, indicating that Komnenić did not believe them and that they were, in fact, at war (Horvat 1989, 290). Generally in fact, while Horvat was approaching the Kosovo question from a Yugoslav perspective, for most Serbian intellectuals-even the Yugoslav-oriented ones-it was predominantly a Serbian national question (Dragović-Soso 2002; Stefanov 2011, 14).

So, taking up Burke's approach $(2015,14)$ once more, in view of the extremely polemical echoes in Horvat's book, we might ask whether the knowledge he 
offered was accepted or rejected? The answer runs along decidedly national lines. Most Serbian writers rejected Horvat's knowledge, while Albanian writers accepted and even appropriated it. Nevertheless, like their Croatian and Slovenian counterparts, regardless of whether they agreed with him or not, both the Serbian and Albanian sides alike showed great interest in Horvat. Despite the sharply polemical reactions, Horvat himself remained optimistic about the rational solution to the Kosovo problem he hoped his book might encourage $(1989,278)$. He was supported in that by philosopher Shkëlzen Maliqi, who stated that by creating opportunities for different views on the Kosovo question Horvat's book had achieved more than all the political plenums and congresses put together (Maliqi 1990, 191). Horvat, however, went further than books and controversies. He was also active in connecting intellectuals, organizing for example a symposium on Kosovo in Split in 1988, and suggesting Yugoslav commemorations be installed to celebrate historical events important to Albanians, although that was not accepted (Horvat 1989, 241-2). Horvat then became directly involved in politics in 1989 with the launch of the Association for the Yugoslav Democratic Initiative (Udruženje za jugoslavensku demokratsku inicijativu, UJDI), which would include many intellectuals of different nationalities involved in the Kosovo controversy (Maliqi 2014, 31-3).

Both Branko Horvat and Darko Hudelist challenged the possibilities and limits of individual engagement. In the SR Croatia during the Kosovo crisis in 1989, individual intellectuals rather than groups of intellectuals were the ones who became involved, and as a rule they opposed the policies of the SR Serbia. They saw the Kosovo crisis as a key matter threatening the very survival of Yugoslavia as a country, something that was more evident among social scientists than among journalists. Predominant among the intellectuals were individuals who sided with socialist Yugoslavia but who were unorthodox, even "heretical", in their thinking. They were not dissidents, nor were they in exile, but as intellectuals in Croatia who published books about Kosovo they confirmed another of Burke's notions, that "displaced ideas often come from displaced people" $(2015,21)$.

\section{Shkëlzen Maliqi: Transnational Intellectual Networks in the Kosovo Crisis}

There were deep entanglements among intellectuals in the whole of Yugoslavia, be it in the sense of cooperation or polemic, and that is particularly true of Shkëlzen Maliqi. Maliqi connects Branko Horvat and Darko Hudelist and confirms that journalists and public intellectuals in the SR Croatia must be assessed within the 
broader Yugoslav context. As the example of Branko Horvat shows, assessment of individual interventions should not ignore their efforts to participate in transnational intellectual networks, which they took to the point of forging new networks in the face of the Kosovo question and the Yugoslav crisis, despite the existing sharp national divisions.

Darko Hudelist spoke to Shkëlzen Maliqi in Start, and in his book on Kosovo (Hudelist 1989, 133-51). Branko Horvat used Maliqi's information in "The Kosovo question”, and Maliqi wrote about Horvat's book in the Zagreb magazine Gordogan (Maliqi 1990, 180-91). Maliqi and Horvat participated in the collective volume Kosovo - Srbija - Jugoslavija (Kosovo, Serbia, Yugoslavia), published in Ljubljana (Gaber and Kuzmanić 1989). Both of them collaborated with intellectuals from the other Yugoslav republics in the Association for the Yugoslav Democratic Initiative (UJDI), the Kosovo branch of which was founded in 1989 under the presidency of Veton Surroi. Surroi himself had been attacked and sanctioned for interviewing Horvat in Rilindja in 1988, at the time of the release of "The Kosovo question" (Hudelist 1989, 117; Horvat 1989, 13, 285-6; Maliqi 2014, 278).

Those few examples show how intellectual networks in Yugoslavia crossed national and republican borders, preserving a Yugoslav intellectual and cultural space. They remained partially intact even after the break-up of Yugoslavia, with participating intellectuals being largely opposed to the new regimes of the 1990s. Again, Shkëlzen Maliqi is a good example. Like many other Kosovo Albanians he had studied in Belgrade because Kosovo had no higher education institutions until the 1960s, and the University of Pristina was established only in 1969. In the late 1980s, Maliqi applied to pursue a doctoral programme in Zagreb (Hudelist 1989, 138; Maliqi 2014, 185). In the meantime, after returning from Belgrade to Pristina in the early 1980s, he had begun arguing with Serbian intellectuals over Kosovo and Serb attitudes to Albanians. However, in 1988 he also criticized Albanian intellectuals. In an interview with Darko Hudelist in Start he offered especially harsh criticism of what he saw as an Albanian "pseudo-intelligentsia” operating at the University of Pristina (Hudelist 1989, 131-51; Maliqi 2014, 175-80).

Because of his criticism of the Albanian university intelligentsia, Maliqi's interview in Start was reprinted by the Belgrade newspaper Politika (Hudelist 1989, 145-6), and his polemics against Serbian intellectuals were picked up by Slovenian, Croatian and Bosnian media who noted him as a critic of both Serbian and Albanian nationalism (Maliqi 2014, passim). Throughout the 1980s, Maliqi had published articles in many Yugoslav newspapers and magazines, and his arguments with Serbian intellectuals had resonated so that the media had portrayed him as the voice of the Kosovar Albanian intellectuals who tended to criticize all forms of nationalism, advocated a Yugoslav orientation, and thereby provoked public controversy. 
Shkëlzen Maliqi similarly embodies another example illustrating how the Yugoslav intellectual field was divided. Croatian and Slovenian intellectuals argued with Serbs, just as Albanian intellectuals did. For example, Maliqi sharply criticized Dimitrije Bogdanović's Knjiga o Kosovu (Book on Kosovo). Published in Belgrade in 1985, the book was a Serbian nationalist perspective on Kosovo (Hudelist 1989, 137; Maliqi 2014, 15-25) and was one of an extremely large number of books on Kosovo published in Belgrade in the 1980s, most of which supported the trail of ideas then dominant in the SR Serbia about Kosovo and the Albanians. They were in fact part of the war of books and newspapers. Maliqi pointed out that people in Belgrade generally knew nothing about Kosovo and that many of them had never been there $(2014,108)$, something that both Hudelist and Horvat pointed out, too. Clearly again, Peter Burke's point about "the 'geopolitics of knowledge', especially the relationship between intellectual centres and their peripheries" (Burke 2015, 33), was at play here.

After the disintegration of Yugoslavia and the horrendous ethnonationalist wars that accompanied it, Maliqi maintained ties with non-government organizations and opposition intellectuals and media in Serbia and Croatia, testifying to the persistence of Yugoslav transnational intellectual networks. Returning to the focus of this study, that raises the question of what happened to the Kosovo question in Croatia during the break-up of Yugoslavia and after?

\section{The Place of Kosovo in Croatian Knowledge Production after 1989}

In a conversation with Darko Hudelist in 1987, Branko Horvat predicted that Kosovo would be the main concern of Yugoslavia's domestic policy for the upcoming five years (Hudelist 1989, 83). In fact he was proved entirely correct until well into 1990, which I shall illustrate by reference to "the war of books" that escalated following the arrest of the Kosovo Albanian politician Azem Vllasi. The Serbian writer Milenko Vučetić published Vllasi in Zagreb in 1989 (second edition 1990; an Albanian translation was published in Zagreb in 1990) under the same imprint that had published Darko Hudelist's "Kosovo: A battle without illusions” and with the same print run of 10,000 copies (Vučetić 1989, 1990a, 1990b). Shkëlzen Maliqi wrote a review for the publisher that focused on how Vučetić presented the context of the show trial against Vllasi and its background. Vučetić's oppositional view of Serbian policies in Kosovo was seconded by Vllasi’s wife Nadira Avdić, who published Za (odbranu) Azema Vllasija: izbor članaka (For (in defence of) Azim Vllasi: A selection of articles) in Ljubljana 
(1989). Azem Vllasi's own comment, Majstori mraka: zatvorski zapisi (Masters of darkness: prison notes) was published in Croatian and Albanian in Zagreb soon after (1990a, 1990b). However, Jevrem Damnjanović's Uspon i pad Azema Vlasija (The rise and fall of Azem Vllasi), had already been published in Belgrade in 1989, demonstrating how the war of books between Serbia on one side and Slovenia and Croatia on the other could engulf even topics such as Vllasi's (1989), although things were not completely bilateral, as the case of Vučetić shows, for he decamped to Croatia to publish his work. However, Kosovski čvor: drešiti ili seći? Izveštaj nezavisne komisije (The Kosovo knot: to untie it or cut it? Report of the independent commission) took an opposing view. The book was published in Belgrade in 1990 as part of the activities of the UJDI and the critical engagement of public intellectuals there (Popović, Janča, and Petovar 1990). In any case and regardless of the specific topic, by 1989 or 1990 anyone who published a book about Kosovo was showing support in one of the two possible ways. It was impossible to escape the "war of books".

Proving Horvat's prediction wrong overall in the worst possible way, it soon became uncomfortably clear that the most important matters were the secession of Slovenia and Croatia, the break-up of Yugoslavia, and the resulting war. Along with Croatian-Serbian relations, Kosovo dominated the attention of the Croatian public in 1989, only to be completely displaced from everyone's minds by the end of 1990, especially after the multiparty elections won by the Croatian Democratic Union (Hrvatska demokratska zajednica, HDZ) and the Serb uprising in Croatia. With Croatia's declaration of independence in 1991, the war in Croatia and later Bosnia and Herzegovina became the main topics. As the "war of books" shifted to other theatres there was almost no interest in Kosovo, and the number of books published in Croatia about Kosovo tailed off to almost nothing as did the number of intellectuals engaged in that area. Mention of Kosovo was now most frequently made in the context of the escalation of the Croat-Serb conflict. Albanians in Kosovo were now portrayed as the victims of the same Greater Serbia policies as Croats, and thus presented as allies in the same struggle (Šeparović and Ademaj 1991; Rilović 1994).

Generally, interest in Croatia in publishing books on Kosovo returned with the 1998-1999 war in Kosovo, the NATO bombing of Serbia between March and June 1999, and the proclamation of Kosovo's independence in February 2008, which was followed by the question of its international recognition. Interestingly, a section of the Croatian public had continued to show interest in Shkëlzen Maliqi even after the disintegration of Yugoslavia, an interest that persists to this day. Erasmus, an opposition magazine in Croatia, published one of Maliqi's articles in 1995 (Maliqi 1995), and in 1999 the opposition newspaper Feral Tribune published an interview with him (Maliqi 2014, 254). At the beginning of the new millennium, 
two Croatian publishing houses embarked on the task of translating two politically influential books. The first was Beogradska zadaća: kako je slaman Milošević (2002) (Mission to Belgrade, 2000) by Martti Ahtisaari, who had been Special Envoy for the Kosovo status process concerning the negotiations he led to resolve the Kosovo crisis and the end of Miloševićs governing of Serbia in 2000. Then came Novi militaristički humanizam: pouke Kosova (2003) (New Militaristic Humanism: Lessons from Kosovo, 1999) by Noam Chomsky, whose focus was on the NATO intervention.

It should be noted that both Darko Hudelist and especially Branko Horvat in the 1990s were opponents of Franjo Tuđman, the first president of independent Croatia, and continued to oppose his legacy after Tudman's death in 1999. However, although the publishing and translation of books on Kosovo continued in the Republic of Croatia in the 1990s and 2000s, after the break-up of Yugoslavia almost no journalist or public intellectual apart from the political scientist Jovan Mirić engaged polemically with the topic. Mirić published a collection of his texts in 2010 under the title Kosovo i druge teme (Kosovo and other topics). A Serb intellectual in Croatia, Mirić had criticized both Milošević's and Tuđman's policies on Serbs in Croatia. The impetus for Mirićs interest in Kosovo was Kosovo's recognition in 2008 by the Republic of Croatia, which was opposed by only a few intellectuals, Mirić among them. Like Hudelist, Horvat and Maliqi before him, Mirić believed that in the Republic of Croatia ignorance reigned about Kosovo. He further maintained that no theoretically nor historically relevant texts had been published in the past 20 years, and that anti-Serb views expressed by Croatian politicians, journalists and intellectuals had dominated (Mirić 2010, 9). While excoriating Milošević, Mirić in his book presented critical assessments of Croatian and Albanian nationalism as well as of international politics. He did not engage with the attitude of Serbian nationalists to Albanians, as he considered Serbs to be the principal victims of the Serbian-Albanian conflict. In that sense, Mirić's book on Kosovo extends the controversies and the "wars of books" waged over the Kosovo question in the 1980s: a good 20 or more years later, Mirić was mainly reiterating the position of Serbian intellectuals of that time.

What position do authors assign to Kosovo in the break-up of Yugoslavia? For Kosovar intellectuals and politicians, the Yugoslav disintegration began in Kosovo, as witness for example Shkëlzen Maliqi's Kosovo i raspad Jugoslavije (Kosovo and the disintegration of Yugoslavia) (2014) and Azem Vllasi's Kosovo, početak raspada (Kosovo, the beginning of disintegration) (2016). A few years earlier, Kosovo had also been the beginning of Yugoslavia's end according to Jovan Mirić's collection of texts (2010). For Croatian scholars, Milošević's policies were comprehensively more important, as were the Croatian and Slovenian reactions to them. The question of whether the break-up of Yugoslavia was incited by the 
abolition of Kosovo's autonomy in 1989, the independence movements in Slovenia and Croatia, or more generally the Yugoslav crisis of the 1980s remains a bone of contention about which scholars' positions differ depending on whether they are from Kosovo, other parts of the former Yugoslavia, or abroad (Marijan 2017; Perović, Roksandić, Velikonja, Höpken, Bieber 2017).

\section{Conclusion}

In the Socialist Republic of Croatia, among politicians, the media and intellectuals the peak of interest in the Kosovo question was around 1989, when it became the main topic of the Yugoslav crisis. Along with works by Darko Hudelist, the public took particular interest in Branko Horvat's book “The Kosovo question” (1989), which in the SR Serbia especially sparked many controversial reactions that became a major episode in the fierce "war of books" in the disintegrating Yugoslavia. The controversy over the crisis in Kosovo can be followed through the activities of both older and more recently formed intellectual networks in Yugoslavia, and after the country's break-up and the 10 years of war that followed. A scholar who connected many of them was the philosopher Shkëlzen Maliqi. In Croatia, interest in Kosovo waned as the domestic crisis worsened. If Kosovo had been considered a Yugoslav matter that also affected the SR Croatia, that was no longer the case after the establishment of independent Croatia and the subsequent wars.

Individuals in Croatia who were involved in the Kosovo crisis have continuously highlighted a lack of knowledge. The ups and downs in the level of interest in Kosovo have been affected by the fact that Kosovo has always been viewed through the prism of Croatian-Serbian relations, and the Serbo-Croatian conflict and war during the 1990s pushed Kosovo itself even further into the background. The "wars of books" stopped after Yugoslavia disintegrated, but there followed a decade of real wars, since when what were once controversies and discussions among authors throughout the Yugoslav space have been narrowed down to fit nation-state borders and thus been caught in fierce methodological nationalism. In that respect the case of Kosovo comes full circle and the "book wars" about the knowledge of it confirm Peter Burke's remarks about conflicted and situated knowledges, in the plural (Burke 2015, 7-14, 33-4). The Kosovo question showcases again and again the substantial importance of knowledge production and its management, and the role of intellectuals.

Acknowledgments: I should like to thank the reviewers for their suggestions, which have significantly improved my article. 


\section{References}

Ahtisaari, M. 2002. Beogradska zadaća: kako je slaman Milošević. Zagreb: Naklada Szabo A3 data. / Ahtisaari, M. 2000. Mission to Belgrade. Helsinki: WSOY Press.

Avdić, N. 1989. Za (odbranu) Azema Vllasija: izbor članaka. Ljubljana: Republiška konferenca ZSMS.

Bieber, F. 2002. "Nationalist Mobilization and Stories of Serb Suffering: The Kosovo Myth from 600th Anniversary to the Present." Rethinking History 6 (1): 95-110.

Bilandžić, D. 2006. Povijest izbliza. Memoarski zapisi 1945-2005. Zagreb: Prometej.

Burke, P. 2015. What Is the History of Knowledge? New York: Wiley.

Chomsky, N. 1999. New Militaristic Humanism: Lessons from Kosovo. London: Pluto Press.

Chomsky, N. 2003. Novi militaristički humanizam: pouke Kosova. Rijeka: Adamić.

Damnjanović, J. 1989. Uspon i pad Azema Vlasija. Belgrade: Politika.

Dragović-Soso, J. 2002. Saviours of the Nation: Serbia's Intellectual Opposition and the Revival of Nationalism. Montreal and Kingston: McGill-Queen's University Press.

Franičević, V. and M. Uvalić, eds. 2000. Equality, Participation, and Transition: Essays in Honour of Branko Horvat. London: Palgrave Macmillan.

Gaber, S. and T. Kuzmanić, eds. 1989. Kosovo - Srbija - Jugoslavija. Ljubljana: Univerzitetna konferenca ZSMS, Knjižnica revolucionarne teorije.

Grandits H., V. Ivanović and B. Janković, eds. 2019. Reprezentacije socijalističke Jugoslavije: preispitivanja i perspektive. Sarajevo and Zagreb: Udruženje za modernu historiju - Srednja Europa.

Hasani, S. 1986a. Kosovo: istine i zablude. Zagreb: Centar za informacije i publicitet.

Hasani, S. 1986b. Kosovska uzrastanja i posrtanja. Belgrade: Vinc.

Horvat, B. 1985. Jugoslavensko društvo u krizi. Zagreb: Globus.

Horvat, B. 1988. Kosovsko pitanje. Zagreb: Globus.

Horvat, B. 1989. Kosovsko pitanje, 2nd ed. Zagreb: Globus.

Hudelist, D. 1989. Kosovo: Bitka bez iluzija. Zagreb: Centar za informacije i publicitet.

Hudelist, D. 2004. Tuđman: biografija. Zagreb: Profil.

Hudelist, D. 2012. Moj beogradski dnevnik: Susreti i razgovori s Dobricom Ćosićem 2006-2011. Zagreb: Profil.

Janković, B. “Povijest knjige i čitanja: novi pristup jugoslavenskom socijalizmu.” In Reprezentacije socijalističke Jugoslavije: preispitivanja i perspektive, edited by H.Grandits, V.Ivanović and B.Janković, 139-50. Sarajevo and Zagreb: Udruženje za modernu historiju - Srednja Europa.

Malcolm, N. 1998. Kosovo: A Short History. New York: New York University Press.

Maliqi, S. 1990. “Kosovo na Balkanu: osvajanje političkoga.” Gordogan 11 (29/30): 180-91.

Maliqi, S. 1995. "Kosovo: Otpor nenasiljem.” Erasmus 10: 6-11.

Maliqi, S. 2014. Kosovo i raspad Jugoslavije. Belgrade: Mostart.

Marijan, D. 2016. "Događanja naroda u Kninu 1989. godine - slom jugoslavenske ustavne konstrukcije u Hrvatskoj." Radovi Zavoda za povijesne znanosti HAZU u Zadru 58: 439-67.

Marijan, D. 2017. Hrvatska 1989-1992: Rađanje države. Zagreb: Hrvatski institut za povijest.

Mirić, J. 2010. Kosovo i druge teme. Zagreb: SKD Prosvjeta.

Pauković, D. 2018. Usred oluje. Politička tranzicija u Hrvatskoj 1989/90. Zagreb: Srednja Europa. Panjković, Z. 1981. Kosovo i albanska iredenta. Rijeka: Jugolinija. 
Perović, L., D. Roksandić, M. Velikonja, W. Höpken and F. Bieber, eds. 2017. Yugoslavia from a Historical Perspective. Belgrade: Helsinki Committee for Human Rights in Serbia.

Popović, S., D. Janča and T. Petovar. 1990. Kosovski čvor: drešiti ili seći? Izveštaj nezavisne komisije. Belgrade: Chronos.

Rilović, A. 1994. Stranputicama Kosova: roman. Zagreb: Nakladni zavod Matice hrvatske.

Šeparović, Z. and E. Ademaj, eds. 1991. Kosovo žrtva: studija i dokumentacija o stradanjima Albanaca na Kosovu. Zagreb: Hrvatsko žrtvoslovno društvo.

Stefanov, N. 2010. “Jargon der eigentlichen Geschichte: Vom Nichtverstehen und dem Fremden. Zur Diskussion um Holm Sundhaussens Geschichte Serbiens in der serbischen Öffentlichkeit.” Südosteuropa. Zeitschrift für Politik und Geselsschaft 58 (2): 220-49.

Stefanov, N. 2011. Wissenschaft als nationaler Beruf. Die Serbische Akademie der Wissenschaften 1944-1992. Tradierung und Modifizierung nationaler Ideologie. Wiesbaden: Harrassowitz 2011.

Vllasi, A. 1990a. Majstori mraka: zatvorski zapisi. Zagreb: Globus.

Vllasi, A. 1990b. Mjeshtrit e errësirës: shënime nga burgu. Zagreb: Globus.

Vllasi, A. 2016. Kosovo, početak raspada. Sarajevo: Šahinpašić.

Vučetić, M. 1989. Vllasi. Zagreb: Centar za informacije i publicitet.

Vučetić, M. 1990a. Vllasi, 2nd ed. Zagreb: Centar za informacije i publicitet.

Vučetić, M. 1990b. Vllasi. Zagreb: Centar za informacije i publicitet (Albanian translation).

\section{Bionote}

Branimir Janković is an assistant professor at the Department of History of the Faculty of Humanities and Social Sciences, University of Zagreb. A historian of modern Yugoslav and Croatian history, his main research interests include the history of historiography and intellectual history. His current work focuses on books as political "bombs" in socialist Yugoslavia. 